\title{
Grass and Plastic Film Mulching Pattern Improve Soil Organic Carbon Pool, Physical Properties, Fertility and Fruit Quality of Ponkan Orchards
}

\section{Zhihao Dong ( $\sim 974170921 @ q q . c o m$ )}

Huazhong Agriculture University https://orcid.org/0000-0002-8523-5911

Zhao-Yu Xue

Huazhong Agriculture University

\section{Qin Chen}

Huazhong Agriculture University

\section{Anoop Kumar Srivastav}

c. Indian Council of Agricultural Research-Central Citrus Research Institute

\section{Muhammad Riaz}

South China Agricultural University

Xiao-Dong Liu

Huazhong Agriculture University

Heng Cui

Huazhong Agriculture University

Qi-Ling Tan

Huazhong Agriculture University

Xue-Cheng Sun

Huazhong Agriculture University

\section{Song-Wei Wu}

Huazhong Agriculture University

Cheng-Xiao Hu

Huazhong Agriculture University

\section{Research Article}

Keywords: fruit quality, organic carbon fractions, plastic and grass mulching, soil physicochemical properties

Posted Date: March 25th, 2021

DOI: https://doi.org/10.21203/rs.3.rs-308925/v1 
License: (c) (i) This work is licensed under a Creative Commons Attribution 4.0 International License. Read Full License 


\section{Abstract}

Aims. Special fertilizer and soil mulching have been used to improve crop yield worldwide. However, the effects of special fertilizer with mulching on soil characteristics of citrus orchards were not yet fully understood. This study aimed at assessing the effects of different mulch patterns including plastic mulching and grass mulching on improving fruit quality of Ponkan and providing a new insight of mulching development in citrus orchards.

Methods. In this study, a two-year field experiment was conducted to investigate the effects of citrus special fertilizer (FR), grass mulching (RGM), and plastic mulching (RPM) on fruit quality, soil organic carbon fractions, physicochemical properties, and plant nutrition in Ponkan citrus orchard.

Results. The study resulted showed that special fertilizer treatment and grass mulching treatment increased Total soluble solid contents by $6.76 \%$ and $3.97 \%$, while plastic mulching decreased Titratable acid contents by $19.44 \%$, resulting in increases of fruit TSS: TA by $6.14 \%, 3.61 \%$, and $22.76 \%$, respectively. Correlation analyses showed that citrus fruit quality was associated with soil bulk density, Total porosity, Capillary porosit, Aeration porosity, Total organic carbon, Readily oxidized organic carbon, Microbial biomass carbon and Soil available phosphorus. Soil physical properties were improved by RPM, but FR and RGM had better effects on soil nutrients and organic carbon, as evidenced by the results of principal component analysis and loading matrix plot.

Conclusions. This study suggested that the different effects of special fertilizer, plastic mulching, and grass mulching on improving fruit quality were associated with their diverse effects on improving soil characteristics.

\section{Introduction}

Soil mulching is an important part of agronomic practices which conserves soil moisture and reduces nutrient loss from soil. The effects of soil mulching management techniques on increasing production of crops such as wheat, maize, winter oilseed rape, and cotton have widely reported in arid and semi-arid regions of the world (Xiao-rui et al. 2002; Zhang et al. 2005; Naudin et al. 2010; Gu et al. 2017; He et al. 2017; Hu et al. 2019; Yadav et al. 2019). Mulching separates the soil and air-environment to conserve soil moisture, and reduces weed infestation and modify soil physical properties, as well as avoids nutrition loss and soil erosion caused by agricultural irrigation and rainfall (Aarstad and Miller 1981; Khatibu et al. 1984; Gholami et al. 2013; Li et al. 2013; Qin et al. 2013; Mo et al. 2016). On the other hand, earlier studies showed that mulching increased soil organic carbon of topsoil by $41 \%$ in the fourth year and by $52 \%$ in the eleventh year (Saroa and Lal 2003). A nine-year effects of soil mulching on soil C and soil bacterial diversity of dryland winter wheat showed that straw mulching increased soil $\mathrm{C}$ content, and plastic film mulching enhanced fungal diversity (Fu et al. 2019). Wang et al. (2019) compared the effects of straw mulching, and plastic film mulching on maize growth, and concluded that both straw mulching and plastic film mulching could increase maize grain yield and above-ground biomass, and straw mulching had great effects on soil intermediate $C$ fractions. Recently, the benefits of soil mulching in regulating soil 
characteristics including organic carbon fractions, soil physicochemical properties and fertility attracted attentions of fruit growers.

Citrus is a perennial woody plant which prone to face soil deterioration and subsequent root damage, ultimately resulting in reduced citrus fruit yield and quality. China is one of the most important production countries, and the citrus industry has been the pillar industry of some city's economy. However, citrus orchards in China are mostly located in hilly areas where the ecosystem is very fragile and short of a welldeveloped irrigation system. Although building of small-scale storage or impounding reservoirs could partly alleviate water shortage, while nutrition loss and soil erosion caused by agricultural irrigation and rainfall are unavoidable (Zhou et al. 2010; Tang et al. 2016; Bagagiolo et al. 2018). Additionally, citrus orchards are mostly established on acidic soils, such as red soil, purple soil, and yellow soil, where the long-term and excessive application of chemical fertilizer aiming at increasing yield not only decrease fertilizer utilization, but also soil fertility (Zhang et al. 2009). Soil surface management including straw mulching and plastic film mulching could significantly control runoff, conserve soil nutrition, and increase fruit yield (Liu et al. 2012). Moreover, plastic film mulching enhanced the activities of acid invertase, sucrose synthase, and reduce activities of cyt-Aco and cyt-IDH, affecting citrus fruit quality (Jiang et al. 2014). A three-year field trial result showed that grass mulching promoted root growth, increased fruit yield, and provided higher species diversity of citrus orchards (Homma et al. 2012). The total soluble solids and titratable acid of citrus fruit play an important role in fruit flavor and market partiality. The fruit flavor is influenced by plant nutrients (Zhou et al. 2018), soil characteristics (Zheng et al. 2015), water stress (Navarro et al. 2010), temperatures, and illumination (Lombard et al. 1965). However, it was obscure how the variations of soil organic carbon pool, physicochemical properties, and soil fertility, caused by soil mulching, affected citrus fruit acidity and sweetness. Here, we compared the effects of grass mulching, plastic film mulching, and special fertilizer on total soluble solids and titratable acid of citrus fruit, soil organic carbon pool, physicochemical properties, and fertility, as well as plant nutrition to address the above issues. We further discussed the potential mechanisms of improvement of fruit quality caused by soil mulching, aiming at providing a new insight to help mulching development in citrus orchards.

\section{Materials And Methods}

\section{Plant material and experimental design}

The field experiment was conducted from 2017 to 2018, with 20-year-old Ponkan (Citrus reticulata Blanco) grafted on trifoliate orange (Poncirus trifoliata (L.) Raf.). The experiment was carried out in Taoyuan Agroecological Experimental Station, Changde, Hunan, China. The physicochemical properties of quaternary red soil $\left(0-20 \mathrm{~cm}\right.$ ) were as follows: $\mathrm{pH}, 4.37$; total organic $\mathrm{C}, 19.86 \mathrm{~g} \mathrm{~kg}^{-1}$; available $\mathrm{N}, 110.79 \mathrm{mg} \mathrm{kg}^{-1}$; available $\mathrm{P}, 13.50 \mathrm{mg} \mathrm{kg}^{-1}$ and available $\mathrm{K}, 53.00 \mathrm{mg} \mathrm{kg}^{-1}$. Four treatments were designed as follows: CK (control or local customary fertilization); FR (special fertilizer with $25 \%$ less total NPK nutrition); RGM (special fertilizer with 25\% less total NPK nutrition, and grass mulching); RPM (based on special fertilizer with $25 \%$ less total NPK nutrition, and plastic film mulching), with three replicates, each treatment, and three Ponkan trees for every replicate. $\mathrm{K}_{2} \mathrm{SO}_{4}\left(\mathrm{~K}_{2} \mathrm{SO}_{4} \geq 51 \%\right), \mathrm{NH}_{4} \mathrm{H}_{2} \mathrm{PO}_{4}\left(\mathrm{NH}_{4} \mathrm{H}_{2} \mathrm{PO}_{4} \geq 48.5 \%\right), \mathrm{CO}\left(\mathrm{NH}_{2}\right)_{2}$ 
$\left(\mathrm{CO}\left(\mathrm{NH}_{2}\right)_{2} \geq 46.4 \%\right)$ were used as fertilizers resource of $\mathrm{CK}$, and special fertilizer for citrus $\left(\mathrm{CO}\left(\mathrm{NH}_{2}\right)_{2} \geq\right.$ $15 \%: \mathrm{NaH}_{2} \mathrm{PO}_{4} \geq 7 \%, \mathrm{~K}_{2} \mathrm{SO}_{4} \geq 13 \%$, with $\mathrm{OM} \geq 10 \%$ ) was used as chemical fertilizers resource of $\mathrm{FR}$, RGM, RPM. Chemical fertilizers were applied in April and July by RGM application around the drip line. Sun shading net mulching was imposed on April 15-16, 2017, fixed with plastic nails. The Trifolium repen seeds of RGM treatment was grown evenly under crown after clearing the weeds on April 15-16, 2017 and April 10-11, 2018 (Fig 1). The design of the experiment is shown in table 1.

\section{Sampling and determination}

On November 20, 2017 and November 20, 2018, approximately 60 randomly leaves from three trees, located at the second or third position of the vegetative branch tip, were selected to create one composite sample. All leaf samples were washed and inactivated at $105^{\circ} \mathrm{C}$ for $30 \mathrm{~min}$ then oven-dried at $70{ }^{\circ} \mathrm{C}$ to a constant weight and ground to fine powder. Leaf samples were digested with $\mathrm{H}_{2} \mathrm{SO}_{4}-\mathrm{H}_{2} \mathrm{O}_{2}$. The $\mathrm{N}, \mathrm{P}, \mathrm{K}$ content was analyzed as Srivastava et al. (1999) described, using the micro-Kjeldahl method for $\mathrm{N}$, colorimetric method for P and flame photometer for K (FP6410, INESA, China).

On November 20, 2018, we drilled three soil holes that $1 \mathrm{~m}-1.2 \mathrm{~m}$ away from trunk (Fig 1 ) per tree and collected $0-20 \mathrm{~cm}$ and $20-40 \mathrm{~cm}$ soil samples, then repeated this process and mixed three trees of the same replication to create one composite sample for nutrients and carbon fractions determination. The soil parameters were measured according to the soil physicochemical analysis handbook (Bao 2000). After removing the stones and organic materials and root debris, every soil sample was divided into two parts, one part was saved at $4{ }^{\circ} \mathrm{C}$ for measurement of soil organic carbon pool, the other part was crushed with a wooden roller after air-drying to pass through a $1 \mathrm{~mm}$ sieve for soil available $\mathrm{N}, \mathrm{P}, \mathrm{K}$ determination. The alkaline hydrolysis diffusion method was used to determine the soil-available N. Available P was determined by Olsen's method. Available $\mathrm{K}$ was extracted with $1 \mathrm{~mol} \mathrm{~L}^{-1} \mathrm{NH}_{4} \mathrm{OAC}$ and determined by flame photometer (FP6410, INESA, China). Soil total organic carbon (TOC), microbial biomass carbon (MBC), and readily oxidized organic carbon (ROC) were determined by $\mathrm{K}_{2} \mathrm{CrO}_{7}-\mathrm{H}_{2} \mathrm{SO}_{4}$ wet oxidation method (Walkley and Black 1934), $\mathrm{CHCl}_{3}$ fumigation-extraction method (Vance et al. 1987), and Centrifugal method (Blair et al. 1995), respectively. Field-moist soil samples $(5.0 \mathrm{~g})$ was used to extract soil dissolved organic carbon (DOC) with $50 \mathrm{~mL}$ deionized water, by shaking for two hours at $180 \mathrm{rpm}$, and then measured DOC by a Vario TOC select analyzer (Elementar). Soil samples were collected from $1 \mathrm{~m}-1.2 \mathrm{~m}$ away from trunk (Fig 1) for determination of physical properties with stainless steel ring-knife and measured as described by Klute and Hartage (1986). Fruit samples were collected in November 2018 which were bagged separately for the determination of fruit quality. Each replication consisted of 24 fruits from three trees were all located at the middle part of the tree crown. The content of fruit total soluble solids (TSS), and titrate acid (TA) were measured as described by Zhang (2014).

\section{Statistical analysis}

Unless otherwise noted, the results are given as means \pm standard error (SE). Data were analyzed using analysis of variance (ANOVA) and the differences between means were determined by the least significant 
difference (LSD) test at $p<0.05$. The SPSS PASW Statistics 18.0 analytical software package, origin Pro 2018 , and Rstudio were used for all statistical analyses and picture production, respectively.

\section{Results}

\section{Effects of special fertilizer and mulching patterns on fruit qualities}

There were no significant differences in fruit TSS (total soluble solids) contents but remarkable variations in TA (titratable acid) and TSS: TA among four treatments (Table 2). Compared with the CK treatment (the control), the FR treatment increased fruit TSS by $6.76 \%$, resulted in a rise of $6.14 \%$ of TSS: TA. The results of RGM showed almost the same TSS, TA, and TSS: TA with FR, but RPM treatment decreased fruit TA content by $19.44 \%$, resulted in $15.66 \%$ higher TSS: TA than FR treatment. The results suggested that special fertilizer could increase TSS content to improve fruit quality and plastic mulching decreased TA content to significantly increase fruit TSS: TA.

\section{Effects of special fertilizer and mulching patterns on plant N, P, K nutrition}

Table 3 shows the effects of special fertilizer and mulching patterns on plant N, P, K nutrition. The plant $\mathrm{N}$ nutrition was significantly related to application period, and plant $\mathrm{K}$ nutrition was not only significantly related to years' change but also with treatment, while the plant $\mathrm{P}$ nutrition was neither related to treatment nor years' change. There were no significant differences in leaf $N, P$, and $K$ contents among four treatments in 2017, while remarkable variations of leaf $\mathrm{K}$ contents were observed in 2018 (Table 3). Compared with control, the FR, RGM, and RPM treatment increased leaf $\mathrm{K}$ content by $8.86 \%, 27.91 \%$, and $9.30 \%$, respectively. It suggested that special fertilizer and mulching patterns could increase plant $\mathrm{K}$ nutrition with increasing application period, especially grass mulching patterns.

\section{Effects of special fertilizer and mulching patterns on soil organic carbon pool of orchard}

There were no significant differences of TOC content at 20-40 cm depth, but remarkable variations in soil at 0-20 cm depth among four treatments (fig 2A). Compared with CK, FR increased soil TOC concentration by $17.76 \%$ of $0-20 \mathrm{~cm}$ depth and $10.13 \%$ of $20-40 \mathrm{~cm}$ depth. The RGM and RPM treatments showed a decrease of $7.92 \%, 19.79 \%$ at $0-20 \mathrm{~cm}$, and $1.35 \%, 10.76 \%$ at $20-40 \mathrm{~cm}$ soil depth, compared to FR treatment. In contrast, special fertilizer and mulching patterns significantly decreased soil DOC content of 0-20 cm and $20-40 \mathrm{~cm}$ soil depths (fig $2 \mathrm{C}, \mathrm{P}<0.05$ ). Soil DOC content of FR, RGM and RPM treatments were decreased $14.37 \%, 23.35 \%, 6.00 \%$ at $0-20 \mathrm{~cm}$ and $17.28 \%, 20.30 \%, 9.02 \%$ at $20-40 \mathrm{~cm}$ soil depths than control. Grass and plastic film mulching significantly increased soil ROC and MBC contents (fig 2B, D). The RGM was superior to RPM in increasing ROC and MBC contents of soil 0-20 cm depth whereas contents of soil 20-40 cm depth were the opposite. Compared with control, RGM and RPM increased soil ROC content by $62.37 \%, 57.48 \%$ of $0-20 \mathrm{~cm}$ and $60.82 \%, 69.65 \%$ of $20-40 \mathrm{~cm}$, and increased MBC content by $30.41 \%, 22.71 \%$ of $0-20 \mathrm{~cm}$ and $11.58 \%, 23.16 \%$ of $20-40 \mathrm{~cm}$, respectively. Collectively, special fertilizer showed a significant advantage in increasing soil TOC contents, while mulching patterns were in favor of organic carbon fractions of citrus orchards. 


\section{Effects of special fertilizer and mulching patterns on soil N, P, K nutrition of orchard}

There were no significant differences in soil available $\mathrm{N}$ and $\mathrm{K}$, but remarkable variations in soil available $\mathrm{P}$ among four treatments (fig 3). The soil available N, P, and K concentrations of FR treatment were not distinguished from the control but increased by $5.04 \%-10.61 \%, 35.50 \%-38.49 \%$, and $0.94 \%-3.70 \%$ compared with the CK treatment. The RGM and RPM significantly increased soil available P concentration and showed an increase of $47.74 \%-53.98 \%$ at $0-20 \mathrm{~cm}$ and $20.31 \%-34.59 \%$ at $20-40 \mathrm{~cm}$ higher than FR treatment. Although there were no significant differences of soil available $\mathrm{N}$ and $\mathrm{K}$ content among $\mathrm{FR}$, RGM, and RPM treatments. The RGM and RPM treatments increased soil available $\mathrm{N}$ by $8.82 \%-10.83 \%$ of $0-20 \mathrm{~cm}$ and decreased by $1.86 \%-4.68 \%$ of $20-40 \mathrm{~cm}$, increased soil available $\mathrm{K}$ by $11.43 \%-12.14 \%$ of $0-20$ $\mathrm{cm}$ and $21.50 \%-29.91 \%$ of $20-40 \mathrm{~cm}$ compared with FR, respectively. These results suggested that special fertilizer and mulching patterns increased soil available N, P, K concentrations, and improved soil fertility of citrus orchards.

\section{Effects of special fertilizer and mulching patterns on soil physicochemical properties of orchard}

There were no significant differences of soil relative water (RW), soil bulk density (SBD), total porosity $(T P)$, capillary porosity (CP), and aeration porosity (AP) but remarkable variations in soil absolute water content (AW) and field moisture capacity (FM) among four treatments (fig 4). Special fertilizer and mulching patterns significantly decreased by $13.01 \%-16.28 \%$ of soil absolute water content and $9.27 \%-9.29 \%$ of field moisture capacity, compared with control, respectively. The ratio of soil three phases of CK, FR, RGM, RPM treatments were 46.37: 27.85: 25.78, 46.83: 24.57: 28.60, 46.85: 23.32: 29.83 and 49.35: 24.23: 26.42, respectively. Compared with control, FR and RGM treatments decreased the proportion of liquid phase but increased vapor phase, while RPM treatment increased the proportion of solid and liquid phase but decreased vapor phase. It suggested that special fertilizer and mulching patterns affected the proportion of solid, liquid, and vapor phase, resulted in variations of physical properties of citrus orchard soil.

\section{Correlations between fruit quality and soil characteristics}

There was a significant relationship between fruit quality and soil characteristics (fig 5). The TA contents were negatively correlated with soil available $\mathrm{P}$ of $20-40 \mathrm{~cm}$ and SBD but positively correlated with AP, TP, and TOC of $20-40 \mathrm{~cm}$. Significant correlations were observed between fruit TSS and AP, CP, and TOC40. The TSS/TA ratio showed a significant relationship with soil characteristics including soil physical, soil organic carbon pool, and nutrition characteristics. There were dramatically positive correlations between TSS: TA and SBD, SP of $20-40 \mathrm{~cm}, \mathrm{MBC}$ of $20-40 \mathrm{~cm}, \mathrm{ROC}$ of $20-40 \mathrm{~cm}$ but negative correlations between TSS: TA and TP. Collectively, it indicated that better fruit quality caused by mulching patterns, (particularly the decreased content of TA), was associated with the changes of soil fertility, physicochemical properties, and organic carbon pool.

Principal component analysis of orchard soil organic carbon pool and physicochemical properties 
The principal component analysis was carried out for every soil characteristic to reflect the effects of special fertilizer and mulching patterns (fig 6). It was observed that PC1 and PC2 accounted for $40.40 \%$ and $23.56 \%$ of the total variance, respectively. It was apparent that the CK treatment and RGM treatment were separated from each other on PC1, while the CK treatment and RPM treatment were separated from each other on PC2. The FR treatment did not separate from CK, RGM, and RPM. It suggested that special fertilizer with soil mulching was superior to special fertilizer alone in affecting soil characteristics. Grass mulching and plastic film mulching separated from the FR treatment on PC1 and PC2 dimensions, respectively. The loading matrix plot showed that the main contributors to PC1 were DOC20, MBC20, ROC20, SP20, SP40, MBC40, DOC40, AW, and ROC40, mainly representing soil fertility and organic carbon while the main contributors to PC1 were the AP, CP, SBD, TP, mainly representing soil physical characteristics. It suggested that mulching led a fundamental role in two different aspects for the improvement of soil characteristics; one thing, affected soil physical characteristic, for another, affected soil fertility and organic carbon.

\section{Discussion}

\section{Special fertilizer and mulching patterns improved citrus fruit quality}

The present study was performed to estimate the effects of special fertilizer and mulching patterns on soil organic carbon pool, soil physicochemical properties, soil fertility, plant nutrition, and fruit quality of Ponkan orchards. Compared to the control, special fertilizer and mulching patterns improved fruit quality. The FR and grass mulching increased TSS content while plastic mulching decreased TA content to increase fruit TSS: TA (Table 2). In our study, the citrus special fertilizer modified the proportion of nitrogen, phosphorus and potassium and added organic matter, basing on the investigation of soil fertility of Hunan Province orchards (Liang 2017). Previous studies demonstrated that balanced fertilization with the 4R Nutrient steward concept as the core was considered to cut the cost and increase fruit yield and quality (Srivastava and Malhotra 2014). Moreover, organic cultivation including organic manures and biofertilizers of citrus could bring a positive effect on fruit quality production (Canali et al. 2012; Toselli et al. 2020). The FR treatment decreased $25 \%$ of total NPK nutrition which seemed to improve nutrient use efficiency and fruit quality. Grass mulching showed almost the same TSS, TA, and TSS: TA of fruit, while plastic mulching significantly decreased TA to improve fruit quality, compared with the FR (table 2). Similarly, a three-year mulching experiment conducted in the experimental farm of National Research for Citrus, Nagpur studied the effects of 5 mulches including plastic mulching, grass mulching, and straw mulching suggested that plastic mulching could decrease fruit acidity (Shirgure et al. 2003). Abouziena et al. (2014) also found the fruit quality with white plastic mulching was the best and the yield with black plastic mulching was the highest, compared with rice straw mulching, maize straw mulching, and crop weed. However, the reported effects of mulching on citrus yield and quality sometimes differed between studies, likely due to variations in citrus varieties, climatic, cultivation pattern, and soil characteristics (Qin et al. 2015). For example, some studies suggested grass mulching could produce lower fruit acidity (Panigrahi et al. 2017) and plastic mulching may increase fruit TA content (Rno et al., 2002). In our research, results of principal component analysis and loading matrix plot suggested that plastic mulching 
played an important role in improving soil physical characteristics while grass mulching had betterimproving effects on soil nutrients and organic carbon (fig 6). Correlation analyses showed that citrus fruit TA was associated with SBD, TP, CP, AP, TOC, and SP, mainly respecting soil physical characteristics. One possible mechanism was that the improvement in different aspects of citrus fruit could be associated with the different effects of special fertilizer and mulching patterns on soil characteristics.

\section{Effects of special fertilizer and mulching patterns on soil characteristics}

It could be ascertained that fertilizer and mulching were associated with the changes of soil characteristics. In the present study, the principal component analysis had big differences of soil characteristics between the $\mathrm{CK}$ treatment and the other three treatments. PC1 separated the FR from CK, and the main contributors were DOC20, MBC20, ROC20, SP20, SP40, MBC40, DOC40, AW, SK40, and SN20 (fig 6). Special fertilizer seemed to improve soil characteristics by affecting soil fertility and organic carbon. Special fertilizer significantly increased soil available-P and TOC contents and tended to increase soil available-N and available-K contents (fig 3 ). The special fertilizer modified the proportion of nitrogen, phosphorus, and potassium as well as added organic matter basing on the investigation of soil fertility of Hunan Province orchards. More fertilizer application was instrumental in increasing soil available nutrients concentrations but also increasing the higher risk of loss, particularly soil available-N and soil available-K (Legaz et al. 1995; Yuan et al. 2002). On the one hand, the special fertilizer increased soil available N, P, K concentrations and improved soil fertility of citrus orchards by balanced fertilizer application. On the other hand, organic matter in special fertilizer treatment played a role not only in increasing soil total carbon but also in increasing soil available nutrients. Long-term field experiments conducted from 1995 evaluated the effects of organic manures on soil nutrients, and results showed that organic manure application could increase soil available-P, soil available-K, soil available-Zn, soil available-Fe, soil available-Mn, soil available-Cu and soil available-Zn contents (Antil and Singh 2007). Soil organic carbon was related to increasing soil available nutrients more than improving water-holding capacity (Kimble et al. 1998). Different organic composts including green waste compost and urban organic waste compost increased soil nitrogen, phosphorous, and potassium (Legaz et al. 1995). Similarly, our results showed that soil organic carbon fractions such as ROC, MBC, and DOC were significantly associated with soil nutrients (fig 5). Our study also showed the effects of mulching on soil characteristics. The principal component analysis showed that CK treatment did not separate from FR treatment, but completely separate from FR treatments with mulching (fig 6). Soil physical characteristics were the main contributors to separate plastic film mulching treatment from the FR treatment, while soil fertility and organic carbon were the main contributors to separate grass mulching treatment from the FR treatment. Similarly, a four-year field experiment conducted in Xiaofuling demonstrated that grass mulching could increase soil organic carbon fractions such as dissolved organic carbon, easily oxidizable organic carbon, light organic carbon and particulate organic carbon (Gu et al. 2016). For the most soils, the effects of mulching on soil physical characteristics varied due to the proportion of solid, liquid, and vapor phases. Plastic mulching effectively reduced soil evaporation but increased topsoil temperatures and soil moisture changing soil aggregation, resulting in soil physical characteristics variations ( $\mathrm{Li}$ et al. 2000). Favorable effects of grass mulching on soil organic carbon and prevention of available P, K, Ca and Mg loss have been widely reported (Rees et al. 
2002; Saroa and Lal 2003). Mechanistic studies suggested that green manuring not only improved soil fertility by increasing soil organic matter and nutrients mineralization potential but also preserve biodiversity and the environment (Hwang et al. 2015; Pittelkow et al. 2015).

\section{Conclusion}

There were no significant differences in fruit TSS (total soluble solids) contents but remarkable variations in TA (titratable acid) and TSS: TA among four treatments. Special fertilizer and grass mulching increased TSS contents by $6.76 \%$ and $3.97 \%$, while plastic mulching decreased TA contents by $19.44 \%$, resulting in improvement of fruit TSS: TA. Soil characteristics were improved by special fertilizer and mulching, and plastic mulching played an important role in improving soil physical characteristics while grass mulching had better-improving effects on soil nutrients and organic carbon. Correlation analyses implied that soil characteristics affected by special fertilizer and mulching patterns may play an important role in the improvement of fruit qualities. Therefore, the better improvement of fruit quality of Ponkan by special fertilizer and soil mulching were associated with the changes in soil characteristics.

\section{Declarations}

\section{Acknowledgments}

This study was funded by the Modern Citrus Industry Technology System of China (CARS-26) and the National Key Research and Development Program of China (No.2017YFD0202000).

\section{Date Availability statement}

The data that support the findings of this study are in the article itself.

\section{Tables}

Table 1, The experiment design

\begin{tabular}{|c|c|c|c|c|c|c|c|}
\hline \multirow[t]{3}{*}{ Treatment } & $\mathrm{K}_{2} \mathrm{SO}_{4}$ & $\mathrm{NH}_{4} \mathrm{H}_{2} \mathrm{PO}_{4}$ & $\mathrm{CO}\left(\mathrm{NH}_{2}\right)_{2}$ & $\begin{array}{l}\text { Special } \\
\text { fertilizer }\end{array}$ & $\begin{array}{l}\text { Trifolium } \\
\text { repens }\end{array}$ & $\begin{array}{l}\text { Sun } \\
\text { shading } \\
\text { net }\end{array}$ & $\begin{array}{l}\text { Total } \\
\text { nutrients }\end{array}$ \\
\hline & \multicolumn{5}{|l|}{$\mathrm{kg}$ tree ${ }^{-1}$} & $\begin{array}{l}\text { light } \\
\text { intensity }\end{array}$ & $\mathrm{kg}$ tree ${ }^{-1}$ \\
\hline & April/June & April/June & April/June & April/June & April & April & \\
\hline CK & $0.3 / 0.3$ & $0.4 / 0.4$ & $0.48 / 0.32$ & 1 & & & 1.07 \\
\hline FR & 1 & 1 & 1 & $1.38 / 0.92$ & & & 0.80 \\
\hline RGM & 1 & 1 & 1 & $1.38 / 0.92$ & 0.055 & & 0.80 \\
\hline RPM & 1 & 1 & 1 & $1.38 / 0.92$ & & $10 \%$ & 0.80 \\
\hline
\end{tabular}


Table 2 Effects of special fertilizer and mulching patterns on fruit qualities

\begin{tabular}{|llll|}
\hline Treatment & TSS $^{\circ}{ }^{\circ}$ Brix $)$ & TA $(\%)$ & TSS: TA \\
\hline CK & $11.84 \pm 0.13 a$ & $0.72 \pm 0.03 a$ & $16.61 \pm 0.89 b$ \\
\hline FR & $12.64 \pm 0.30 a$ & $0.72 \pm 0.03 a$ & $17.63 \pm 0.36 \mathrm{~b}$ \\
\hline RGM & $12.31 \pm 0.37 \mathrm{a}$ & $0.73 \pm 0.07 \mathrm{a}$ & $17.21 \pm 1.12 \mathrm{~b}$ \\
\hline RPM & $11.80 \pm 0.01 \mathrm{a}$ & $0.58 \pm 0.02 \mathrm{~b}$ & $20.39 \pm 0.49 \mathrm{a}$ \\
\hline
\end{tabular}

Note: TSS Total soluble solid; TA Titratable acid; Vc Vitamin C. Different lowercase letters indicate significant differences among the treatments by Duncan-test $(P<0.05, n=3)$.

Table 3 Effects of special fertilizer and mulching patterns on plant N, P, K nutrition

\begin{tabular}{|c|c|c|c|c|}
\hline Year & Treatment & Total-N (\%) & Total-P (\%) & Total-K (\%) \\
\hline \multirow[t]{4}{*}{2017} & CK & $2.27 \pm 0.23 a$ & $0.118 \pm 0.004 a$ & $0.76 \pm 0.05 a$ \\
\hline & FR & $2.25 \pm 0.11 a$ & $0.128 \pm 0.004 a$ & $0.70 \pm 0.09 a$ \\
\hline & RGM & $2.56 \pm 0.13 a$ & $0.128 \pm 0.011 a$ & $0.89 \pm 0.09 a$ \\
\hline & RPM & $2.51 \pm 0.03 a$ & $0.130 \pm 0.004 a$ & $0.79 \pm 0.11 a$ \\
\hline \multirow[t]{4}{*}{2018} & CK & $2.69 \pm 0.04 a$ & $0.116 \pm 0.005 a$ & $0.79 \pm 0.04 b$ \\
\hline & FR & $3.03 \pm 0.15 a$ & $0.124 \pm 0.001 a$ & $0.86 \pm 0.04 b$ \\
\hline & RGM & $2.91 \pm 0.05 a$ & $0.124 \pm 0.003 a$ & $1.10 \pm 0.05 a$ \\
\hline & RPM & $2.74 \pm 0.12 \mathrm{a}$ & $0.116 \pm 0.004 a$ & $0.94 \pm 0.11 \mathrm{ab}$ \\
\hline \multirow[t]{3}{*}{ F Value } & Year & $25.923^{\star \star}$ & 2.550 & $5.808^{\star \star}$ \\
\hline & Treatment & 1.478 & 1.249 & $4.025^{\star}$ \\
\hline & Interaction & 1.699 & 0.460 & 1.161 \\
\hline
\end{tabular}

Notes: Different lowercase letters indicate significant differences among the treatments by Duncan-test $(P<0.05, n=3)$; *: significant at the $p<0.05$ level; $* *$ : significant at the $p<0.01$ level.

\section{References}


Aarstad JS, Miller DE (1981) Effects of small amounts of residue on furrow erosion. Soil Science Society of America Journal 45:116-118

Abouziena H, El-Sayed A, Samir R (2014) ARTICLE INFO ABSTRACT Effect of Bio-Organic Fertilizers, Hoeing and Polyethylene Mulch on Weeds, the Citrus Nematode (Tylenchulus semipenetrans) and Yield of Mandarin Trees in Egypt. 2:10-26

Antil RS, Singh M (2007) Effects of organic manures and fertilizers on organic matter and nutrients status of the soil. Archives of Agronomy and Soil Science 53:519-528

Bagagiolo G, Biddoccu M, Rabino D, Cavallo E (2018) Effects of rows arrangement, soil management, and rainfall characteristics on water and soil losses in Italian sloping vineyards. Environmental research 166:690-704

Bao SD (2000) Agro-chemical analysis of soil. Agricultural Publish House of China, Beijing

Blair GJ, Lefroy RD, Lisle L (1995) Soil carbon fractions based on their degree of oxidation, and the development of a carbon management index for agricultural systems. Australian journal of agricultural research 46:1459-1466

Canali S, Roccuzzo G, Tittarelli F, et al (2012) Organic Citrus: Soil fertility and plant nutrition management. In: Advances in citrus nutrition. Springer, pp 353-368

Fu X, Wang J, Sainju UM, et al (2019) Soil microbial community and carbon and nitrogen fractions responses to mulching under winter wheat. Applied Soil Ecology 139:64-68

Gholami L, Sadeghi SH, Homaee M (2013) Straw mulching effect on splash erosion, runoff, and sediment yield from eroded plots. Soil Science Society of America Journal 77:268-278

Gu C, Liu Y, Mohamed I, et al (2016) Dynamic changes of soil surface organic carbon under different mulching practices in citrus orchards on sloping land. PLoS One 11:e0168384

Gu X-B, Li Y-N, Du Y-D (2017) Biodegradable film mulching improves soil temperature, moisture and seed yield of winter oilseed rape (Brassica napus L.). Soil and Tillage Research 171:42-50

He G, Wang Z, Ma X, et al (2017) Wheat yield affected by soil temperature and water under mulching in dryland. Agronomy Journal 109:2998-3006

Homma SK, Tokeshi H, Mendes LW, Tsai SM (2012) Long-term application of biomass and reduced use of chemicals alleviate soil compaction and improve soil quality. Soil and Tillage Research 120:147-153

Hu Y, Ma P, Zhang B, et al (2019) Exploring optimal soil mulching for the wheat-maize cropping system in sub-humid drought-prone regions in China. Agricultural Water Management 219:59-71 
Hwang HY, Kim GW, Lee YB, et al (2015) Improvement of the value of green manure via mixed hairy vetch and barley cultivation in temperate paddy soil. Field Crops Research 183:138-146

Jiang N, Jin L-F, da Silva JAT, et al (2014) Activities of enzymes directly related with sucrose and citric acid metabolism in citrus fruit in response to soil plastic film mulch. Scientia Horticulturae 168:73-80

Khatibu Al, Lal R, Jana RK (1984) Effects of tillage methods and mulching on erosion and physical properties of a sandy clay loam in an equatorial warm humid region. Field Crops Research 8:239-254

Kimble JM, Follett RF, Cole CV (1998) The potential of US cropland to sequester carbon and mitigate the greenhouse effect. CRC Press

Klute A, Page AL (1986) Methods of soil analysis. Part 1. Physical and mineralogical methods; Part 2. Chemical and microbiological properties. American Society of Agronomy, Inc.

Legaz F, Serna MD, Primo-Millo E (1995) Mobilization of the reserve N in citrus. Plant and soil 173:205210

Li SX, Wang ZH, Li SQ, et al (2013) Effect of plastic sheet mulch, wheat straw mulch, and maize growth on water loss by evaporation in dryland areas of China. Agricultural water management 116:39-49

Li X-Y, Gong J-D, Wei X-H (2000) In-situ rainwater harvesting and gravel mulch combination for corn production in the dry semi-arid region of China. Journal of arid environments 46:371-382

Liu Y, Tao Y, Wan KY, et al (2012) Runoff and nutrient losses in citrus orchards on sloping land subjected to different surface mulching practices in the Danjiangkou Reservoir area of China. Agricultural Water Management 110:34-40

Lombard PB, Stolzy LH, Garber MJ, Szuszkiewicz TE (1965) Effects of climatic factors on fruit volume increase and leaf water deficit of citrus in relation to soil suction. Soil Science Society of America Journal 29:205-208

Mo F, Wang J-Y, Xiong Y-C, et al (2016) Ridge-furrow mulching system in semiarid Kenya: A promising solution to improve soil water availability and maize productivity. European Journal of Agronomy 80:124136

Naudin K, Gozé E, Balarabe O, et al (2010) Impact of no tillage and mulching practices on cotton production in North Cameroon: a multi-locational on-farm assessment. Soil and Tillage Research 108:6876

Navarro JM, Pérez-Pérez JG, Romero P, Botía P (2010) Analysis of the changes in quality in mandarin fruit, produced by deficit irrigation treatments. Food Chemistry 119:1591-1596

Panigrahi P, Srivastava AK, Panda DK, Huchche AD (2017) Rainwater, soil and nutrients conservation for improving productivity of citrus orchards in a drought prone region. Agricultural Water Management 
Pittelkow CM, Liang X, Linquist BA, et al (2015) Productivity limits and potentials of the principles of conservation agriculture. Nature 517:365-368

Qin W, Chi B, Oenema O (2013) Long-term monitoring of rainfed wheat yield and soil water at the loess plateau reveals low water use efficiency. Plos one 8:e78828

Qin W, Hu C, Oenema O (2015) Soil mulching significantly enhances yields and water and nitrogen use efficiencies of maize and wheat: a meta-analysis. Scientific reports 5:16210

Rees HW, Chow TL, Loro PJ, et al (2002) Hay mulching to reduce runoff and soil loss under intensive potato production in northwestern New Brunswick, Canada. Canadian Journal of Soil Science 82:249-258

Rno I-R, Kim Y-H, Koh S-U, et al (2002) Effect of root restriction and polyethylene film mulching on the fruit quality of satsuma mandarin (Citrus unshiu Marc. cv. Uenowase). Horticultural Science \& Technology 20:325-329

Saroa GS, Lal R (2003) Soil restorative effects of mulching on aggregation and carbon sequestration in a Miamian soil in central Ohio. Land Degradation \& Development 14:481-493

Shirgure PS, Sonkar RK, Singh S, Panigrahi P (2003) Effect of different mulches on soil-moisture conservation, weed reduction, growth and yield of drip-irrigated Nagpur mandarin (Citrus reticulata). Indian Journal of Agricultural Science 73:148-152

Srivastava AK, Kohli RR, Dass HC, et al (1999) Evaluation of the nutritional status of Nagpur mandarin (Citrus reticulata Blanco) by foliar sampling. Tropical Agriculture-London Then Trinidad- 76:93-98

Srivastava AK, Malhotra SK (2014) Nutrient Management in Fruit Crops. Indian Journal of Fertilisers 72

Tang P, Ye R, Shang Y, You G (2016) Characteristics of soil pH and available NPK contents of citrus orchards in Chongqing Sanxia reservoir area. Guizhou Agricultural Sciences 44:96-105

Toselli M, Baldi E, Cavani L, Sorrenti G (2020) Nutrient management in fruit crops: An organic way. In: Fruit Crops. Elsevier, pp 379-392

Vance ED, Brookes PC, Jenkinson DS (1987) An extraction method for measuring soil microbial biomass C. Soil biology and Biochemistry 19:703-707

Walkley A, Black IA (1934) An examination of the Degtjareff method for determining soil organic matter, and a proposed modification of the chromic acid titration method. Soil science 37:29-38

Xiao-rui W, Sheng-lu Z, Shao-hua WU (2002) Evapotranspiration, yield and crop coefficient of irrigated maize under straw mulch conditions. Progress in Geography 21:583-592 
Yadav GS, Das A, Lal R, et al (2019) Impact of no-till and mulching on soil carbon sequestration under rice (Oryza sativa L.)-rapeseed (Brassica campestris L. var. rapeseed) cropping system in hilly agro-ecosystem of the Eastern Himalayas, India. Agriculture, Ecosystems \& Environment 275:81-92

Yuan DH, Wang ZQ, Guo XB, et al (2002) Properties of soil and water loss and organic carbon loss from small watershed under different land use patterns in red soil area. Journal of Soil and Water Conservation $16: 24-28$

Zhang W, Xu M, Wang B, Wang X (2009) Soil organic carbon, total nitrogen and grain yields under longterm fertilizations in the upland red soil of southern China. Nutrient cycling in agroecosystems 84:59-69

Zhang X-Y, Chen S-Y, Pei D, et al (2005) Evapotranspiration, yield and crop coefficient of irrigated maize under straw mulch. PEDOSPHERE (미) 15:576-584

Zhang Y, Hu C-X, Tan Q-L, et al (2014) Plant nutrition status, yield and quality of satsuma mandarin (Citrus unshiu Marc.) under soil application of Fe-EDDHA and combination with zinc and manganese in calcareous soil. Scientia Horticulturae 174:46-53

Zheng C-S, Lan X, Tan Q-L, et al (2015) Soil application of calcium and magnesium fertilizer influences the fruit pulp mastication characteristics of Nanfeng tangerine (Citrus reticulata Blanco cv. Kinokuni). Scientia Horticulturae 191:121-126

Zhou X, Shi X, Sun P, et al (2010) Status of soil fertility in citrus orchards of Chongqing Sanxia Reservoir Area. Plant Nutrition and Fertilizer Science 16:817-823

Zhou Y, He W, Zheng W, et al (2018) Fruit sugar and organic acid were significantly related to fruit Mg of six citrus cultivars. Food chemistry 259:278-285

\section{Figures}




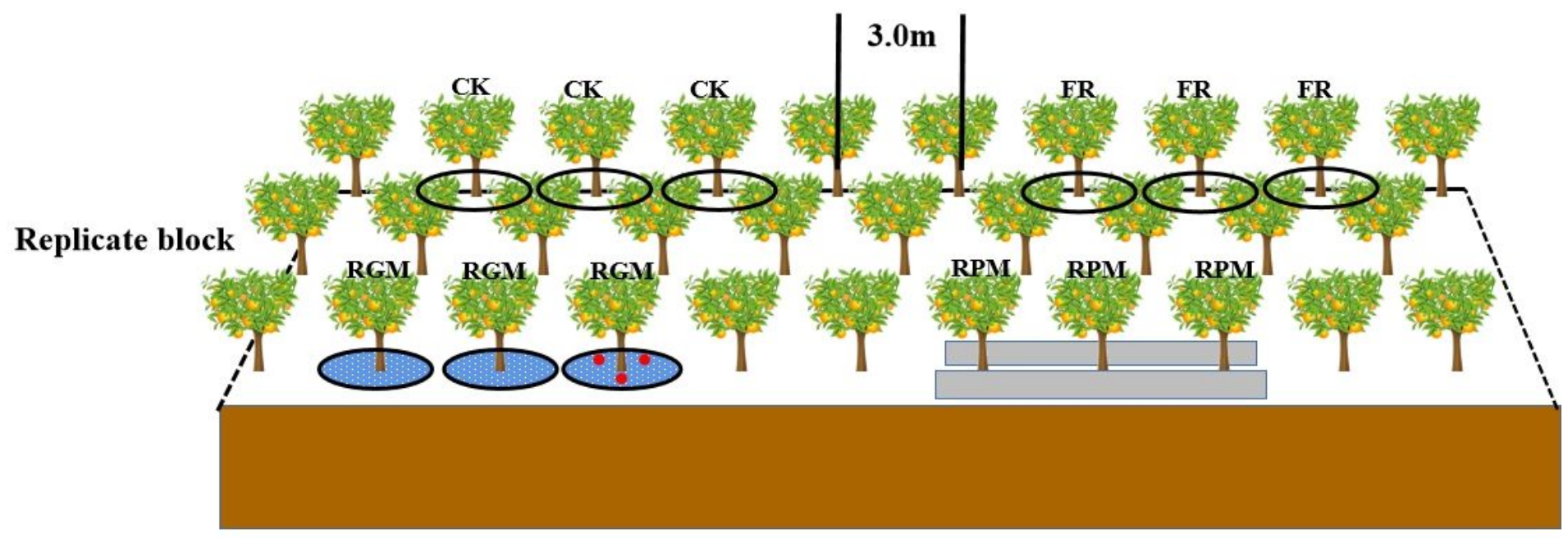

: Sun shading net mylching area

: Dressing furrow

: Trifolium repen growing area

: Soil sample collecting hole

Figure 1

Schematic diagram of the experimental design.
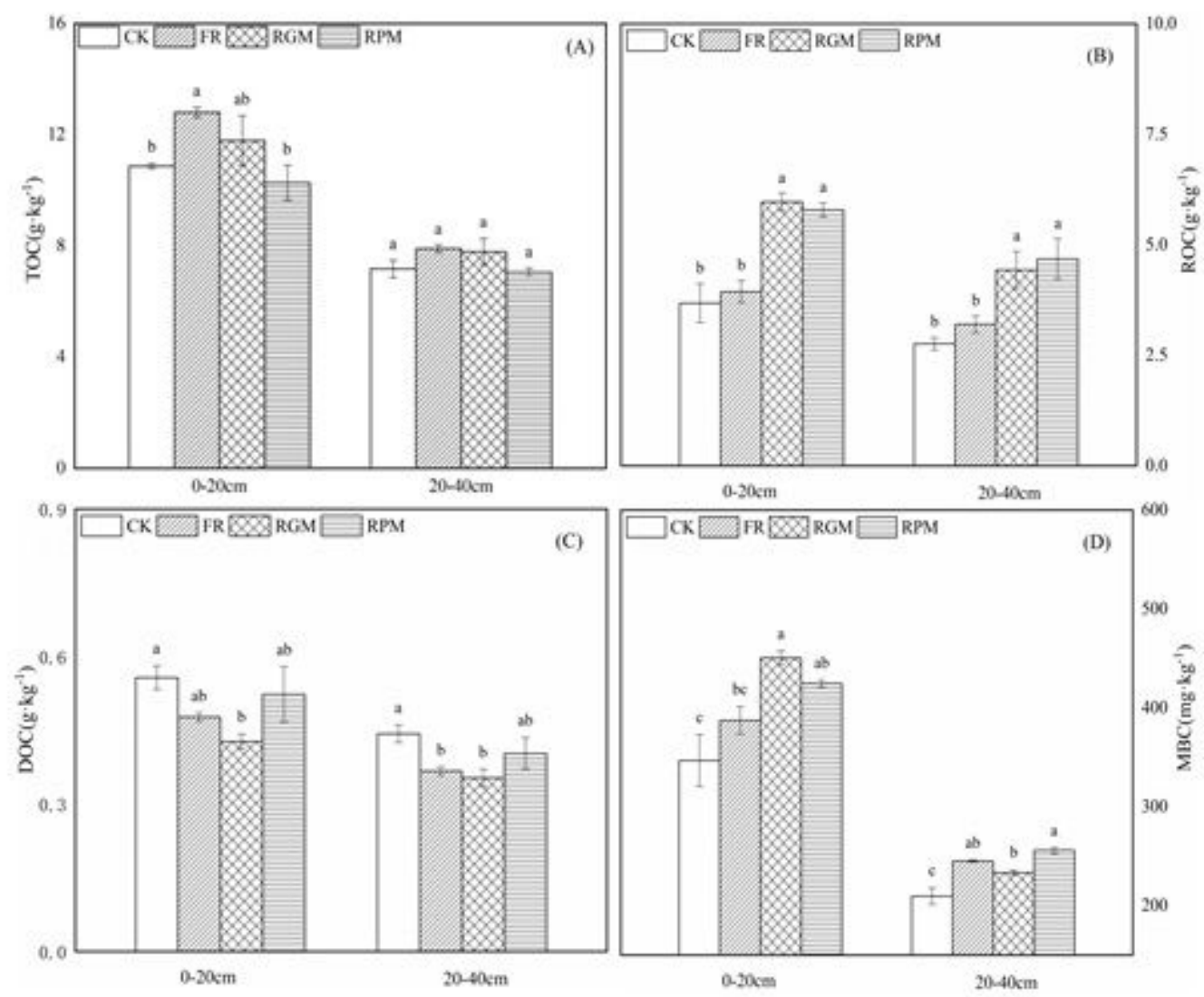

Figure 2

Effects of special fertilizer and mulching patterns on soil organic carbon pool of orchard Note: TOC: total organic carbon; ROC: readily oxidized organic carbon; DOC: dissolved organic carbon; MBC: microbial 
biomass carbon; Different lowercase letters indicate significant differences among the treatments by Duncan-test $(P<0.05, n=3)$.

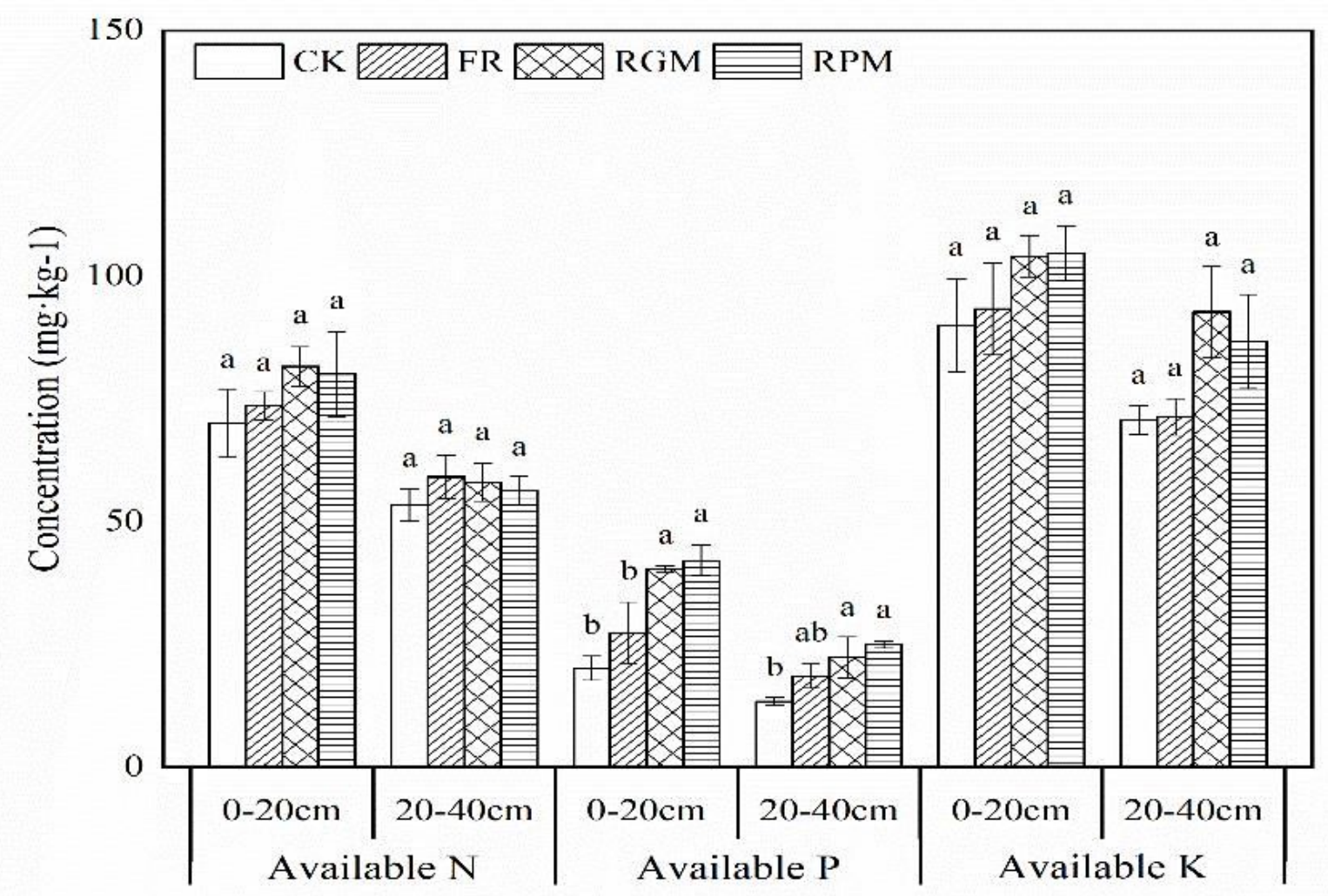

Figure 3

Effects of special fertilizer and mulching patterns on soil N, P, K nutrition of orchard Note: Different lowercase letters indicate significant differences among the treatments by Duncan-test $(P<0.05, n=3)$. 


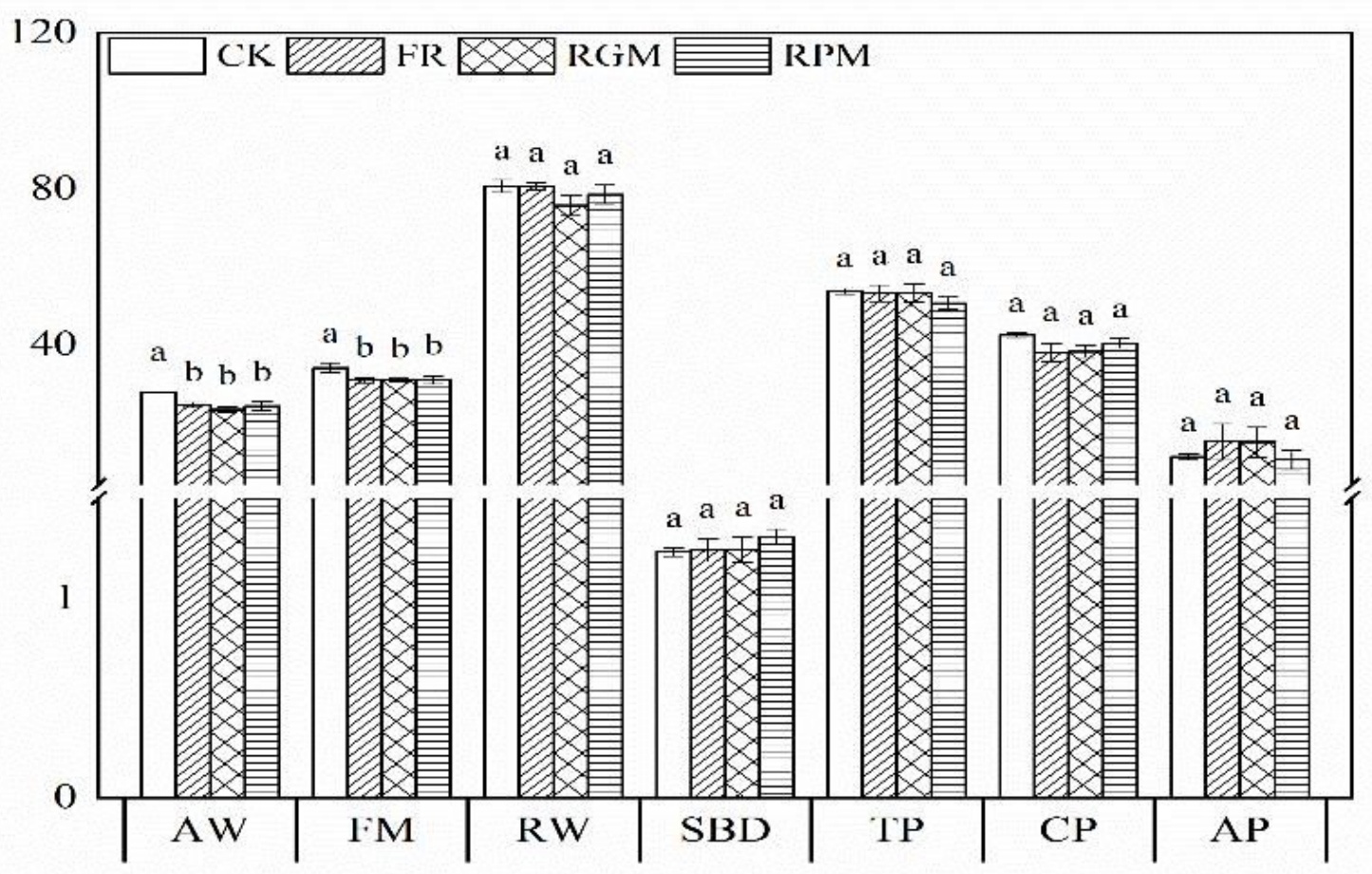

Figure 4

Effects of special fertilizer and mulching patterns on soil physicochemical properties of orchard Note: AW: Absolute water content; FM: Field moisture capacity; RW: Relative water; SBD: soil bulk density; TP: Total porosity; CP: Capillary porosity; AP: Aeration porosity; Different lowercase letters indicate significant differences among the treatments by Duncan-test $(P<0.05, n=3)$. 


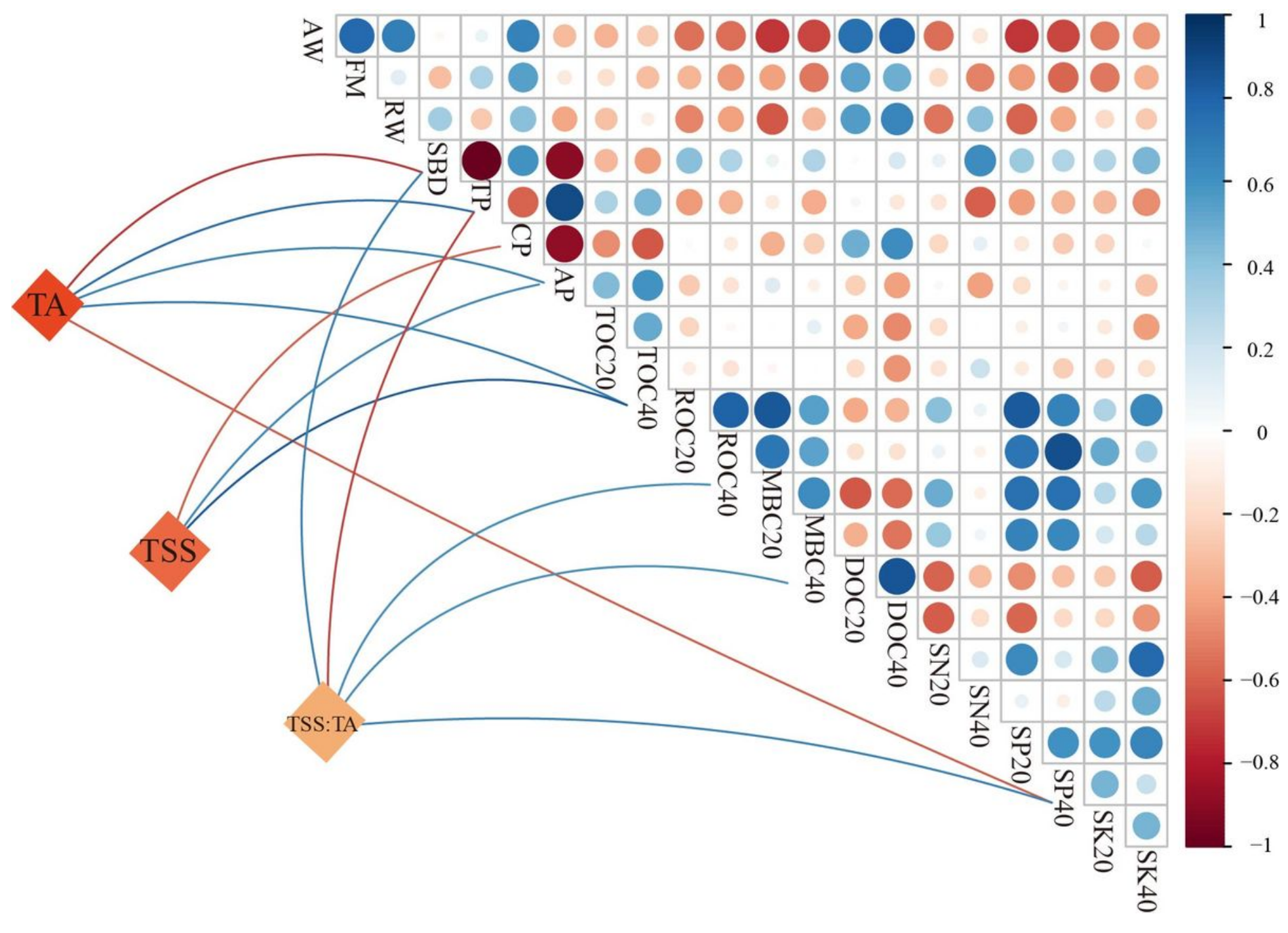

Figure 5

Correlation analyses of fruit quality and soil characteristics Note: SN20: soil available N ( $0-20 \mathrm{~cm})$; SN40: soil available N (20-40cm); SP20: soil available P ( 0-20cm); SP40: soil available P ( $20-40 \mathrm{~cm})$; SK20: soil available K ( 0-20cm); SK40: soil available K ( $20-40 \mathrm{~cm})$; AW: Absolute water content; FM: Field moisture capacity; RW: Relative water; SBD: soil bulk density; TP: Total porosity; CP: Capillary porosity; AP: Aeration porosity; TOC20: total organic carbon ( $0-20 \mathrm{~cm})$; TOC40: total organic carbon ( $20-40 \mathrm{~cm})$; ROC20: readily oxidized organic carbon ( $0-20 \mathrm{~cm})$; ROC40: readily oxidized organic carbon (20-40 cm); DOC20: dissolved organic carbon ( 0-20cm); DOC40: dissolved organic carbon (20-40cm); MBC20: microbial biomass carbon ( 0-20cm); MBC40: microbial biomass carbon (20-40cm). Different colour (from blue to red) represented pearson correlation. 

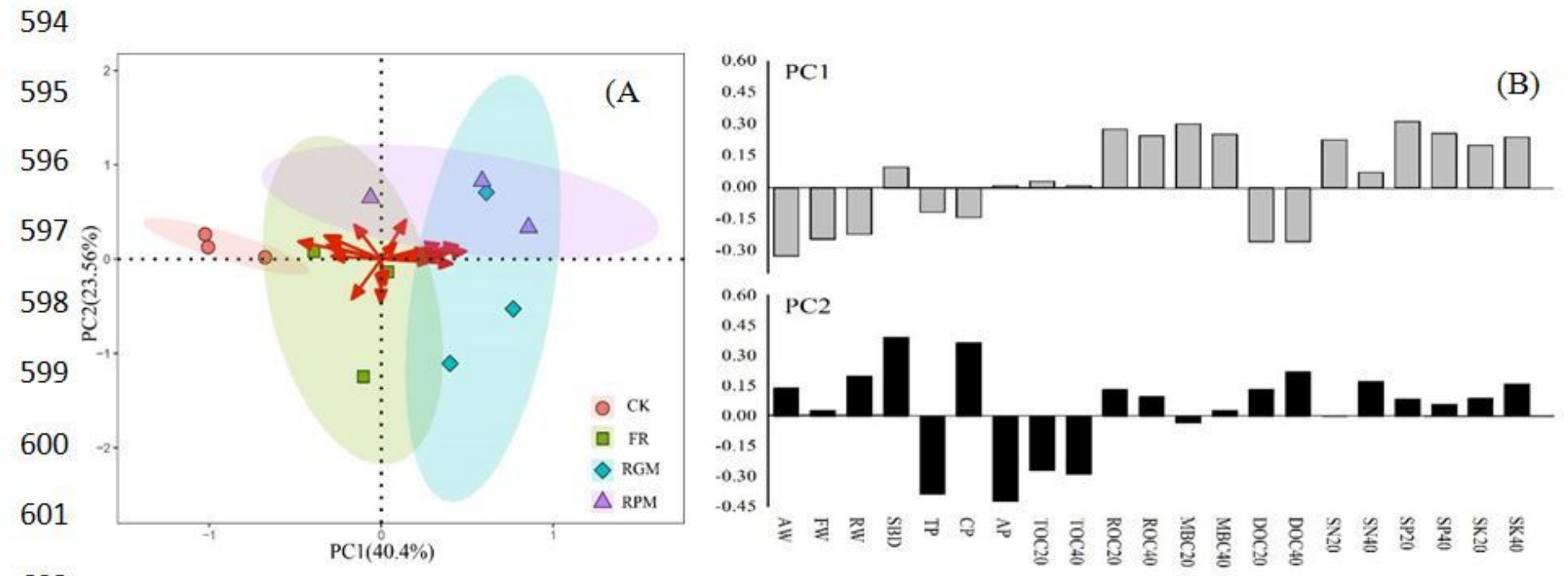

602

\section{Figure 6}

Principal component score plot (A) and principal component loading value (B) of soil physical, soil organic carbon pool, and nutrition characteristics Principal component analysis (PCA) is showing the effect of different treatments on the soil characteristics. The ellipse is the $95 \%$ confidence zone. TOC20: total organic carbon (0-20cm); TOC40: total organic carbon $(20-40 \mathrm{~cm})$; ROC20: readily oxidized organic carbon $(0-20 \mathrm{~cm})$; ROC40: readily oxidized organic carbon $(20-40 \mathrm{~cm})$; DOC20: dissolved organic carbon $(0-20 \mathrm{~cm})$; DOC40: dissolved organic carbon (20-40cm); MBC20: microbial biomass carbon (0-20cm); MBC40: microbial biomass carbon $(20-40 \mathrm{~cm})$; SN20: soil available N $(0-20 \mathrm{~cm})$; SN40: soil available N $(20-40 \mathrm{~cm})$; SP20: soil available P (0-20cm); SP40: soil available P $(20-40 \mathrm{~cm})$; SK20: soil available K $(0-20 \mathrm{~cm})$; SK40: soil available K (20-40cm); AW: Absolute water content; FM: Field moisture capacity; RW: Relative water; SBD: soil bulk density; TP: Total porosity; CP: Capillary porosity; AP: Aeration porosity. 